\title{
The service sector in the free-trade agreement between the EU and Singapore: closing the gap between policy and business realities
}

\author{
Claes G. Alvstam ${ }^{1}$ - Erja Kettunen ${ }^{2} \cdot$ Patrik Ström $^{1}$
}

Received: 9 May 2016 / Revised: 13 October 2016 / Accepted: 8 November 2016 /

Published online: 1 December 2016

(C) The Author(s) 2016. This article is published with open access at Springerlink.com

\begin{abstract}
The aim of this paper is to investigate how new rules and practices in multilateral, regional and bilateral trade negotiations related to the services industries can be adopted and implemented at the business level, using the recently concluded free-trade agreement (FTA) negotiations between the EU and Singapore as an illustrative case. The purpose is to put the services sector into the larger framework of business service interaction between the EU and the outside world by identifying crucial subsectors within the services industries and their relations to physical, 'visible' production and trade. Furthermore, to assess the prospects of 'multilateralising' regional trade agreements within the service sector, through the ambitions by both parties to make bilateral and interregional FTAs and EPAs more compatible and mutually comparable with the multilateral GATS' rules. The EU-Singapore FTA is an agreement that became a 'second-best' solution of the stalled interregional EU-ASEAN negotiation, taking place 2006-2009. It can nevertheless be seen as a 'WTO-plus' endeavour, since it aims at reaching beyond what is under negotiation in the likewise stalled Doha Development Agenda within the WTO framework, particularly in the fields of business services, public procurement, intellectual property rights, trade-related investment measures, and, generally, competition rules. Since both parties already apply low or zero tariffs in most sectors of manufacturing, the main issues in the negotiations were related to services in general and knowledge-intensive business services in particular, with an emphasis on technical barriers to trade. To what extent will there be a true mutual opening up of the service markets between the two parties as a result of the agreement, and what technical and mental barriers remain? This FTA, if successfully implemented, can also pave the way for a revitalisation of the 'paused' EU-ASEAN talks, in which
\end{abstract}

Claes G. Alvstam

claes.alvstam@handels.gu.se

1 Centre for International Business Studies, School of Business, Economics and Law, University of Gothenburg, P.O. Box 610, 40530 Göteborg, Sweden

2 Economic geography, Turku School of Economics, University of Turku, Turku, Finland 
issues related to services were most controversial. Furthermore, it should also be seen in the global context of parallel and overlapping existing agreements or proposed talks, e.g. FTAAP, RCEP, TTIP and TPP, as well as the plurilateral TiSA initiative. In this respect, it can also be considered a test of the EU 'Global Europe' initiative, launched in 2006, and its follow-up communications from the Commission - the latest so far by the 'Trade-for-All' document in October 2015. The paper takes a combined policy- and firm-level approach, by investigating the already reached as well as the potential future impacts by the actors at both sides of the agreement through interviews with diplomatic officials representing EU, ASEAN and separate member-states within both parties, as well as with EU-originated service firms operating in Singapore. A major conclusion is that the business sector sees little direct impact of the future FTA, and that most companies stick to an 'ad-hoc' approach to meet and to overcome trade barriers rather than building a comprehensive strategy regarding how to behave after that the agreement has come into force. On the other hand, most companies are positive to the agreement as such but would welcome resumed EU-ASEAN talks, since the most troublesome remaining barriers are related to doing business with neighbouring countries in the region, using Singapore as the hub for transfer of knowledge-based services.

\section{Background and objective}

The aim of this paper is to contribute to the understanding of how new rules and practises related to the services industries in multilateral, regional and bilateral trade negotiations are received at the business level, using the recently concluded comprehensive free-trade agreement (FTA) negotiations between the EU and Singapore (EUSFTA) as an illustrative case. ${ }^{1}$ Services with different levels of knowledge content have continuously become more important for emerging economies in East and Southeast Asia and are seen to be a vital part of the economic transformation in the region (ADB 2012, 2014, p. 47ff). The services sector should in this respect be put into the larger framework of business interaction between the EU and the outside world by identifying crucial sub-sectors within the services industries and their relations to physical, 'visible' trade.

The decision by the UK to commence exit negotiations from the EU in April 2017, following the results of the referendum in June 2016, will affect the implementation of an EUSFTA in several ways. From a Singaporean perspective, the EU market area covered by the agreement will decrease by $17 \%$ and by that reduce its potential benefits. The UK has traditionally also been the most important trade and investment partner for Singapore within the EU, even though its role has substantially declined over the years. Furthermore, the UK share of Singapore's trade with the EU is higher in

\footnotetext{
${ }^{1}$ For full text, see 'EU-Singapore Free Trade Agreement. Authentic text' as of May 2015. Brussels, 29 June 2015. European Commission, Directorate-General for Trade 2015a. http://trade.ec.europa. eu/doclib/docs/2013/september/tradoc_151729.pdf. Even though the negotiations were declared concluded in December 2012, and officially completed in October 2014, after investment provisions had been added to the agreement, there is at the time of writing (October 2016) some time remaining until the FTA will come into practical operation. Following frequent EU-internal discussions between the Commission and EU member states on the division of competence in the EU's FTAs, the Commission in October 2014 decided to request an opinion from the EU Court of Justice on the competence to sign and ratify a trade agreement with Singapore. A hearing was held in September 2016 and the final ruling by the Court is expected in the spring of 2017. Only thereafter can the agreement be provisionally applied (if so agreed) and enter into force.
} 
services than in goods, which means that the service sector parts of the EUSFTA will be more affected than manufacturing after the UK's exit. From the UK perspective, on the other hand, a new bilateral trade agreement with Singapore has to be negotiated separately after a formal exit in 2019-2020, a process that presumably will take several years to conclude. However, since the uncertainty regarding the scope and compass of UK's separation from the EU will last for the next years, notably concerning its continuous participation in the single internal market as well as in the customs union, this paper treats UK as a still remaining member of the EU with all its benefits and obligations.

Singapore's total trade in services amounted to 388 billion SGD in $2014 .^{2}$ This is about $28 \%$ of its total turnover in trade in goods and services, which is slightly higher than the world average. However, it is in Singapore's case reasonable to deduct the reexports, which adds a considerable amount to total trade. When only domesticgenerated export is accounted for, the share of service trade to total trade in goods and services increases to $34 \%$. If, in addition, the oil trade is excluded from the figures, Singapore's service trade amounted to more than $55 \%$ of the Non-oil Domestic Trade (NODT) in 2014. EU accounts for about $18 \%$ of Singapore's trade in services, in which Singapore runs a deficit with an export/import ratio of 0.82 in 2014 , and is also Singapore's largest partner in service trade, exceeding USA. Accordingly, it is reasonable to pay considerable attention to the rules and regulations around trade in services in the EUSFTA.

Furthermore, it is relevant to assess the prospects of 'multilateralising' regional trade agreements within the service sector, through the ambitions on the EU part to make bilateral FTAs more compatible and mutually comparable with the multilateral 'General Agreement on Trade in Services' (GATS) rules (Baldwin 2006; Baldwin and Thornton 2008; Baldwin et al. 2009; François and Hoekman 2010; WTO 2011; Lindberg and Alvstam 2012a, Hamanaka 2014, p. 26ff) as well as in the parallel plurilateral 'Trade in Services Agreement' (TiSA) talks, in which the EU takes part but Singapore does not. The EUSFTA is a bilateral agreement that became the 'secondbest' solution of the stalled interregional EU negotiation with the 'Association of Southeast Asian Nations' (ASEAN), taking place 2007-2009. It can be seen as a 'WTO-plus' endeavour, since it aims at reaching beyond what is under negotiation in the delayed 'Doha Development Agenda' (DDA) within the WTO framework, particularly in the fields of business services, public procurement, intellectual property rights, trade-related investment measures and, generally, competition rules. Since both parties already apply a low- or even zero-tariff system in most sectors of manufacturing, the main issues in the negotiations were related to non-tariff barriers and technical barriers to trade in services in general and knowledge-intensive business services in particular.

The research questions formulated for the study are first, to what extent will there be a true mutual opening-up of the services markets among the affected parties, and what technical and mental barriers remain? Second, how do the affected service sectors react and respond to the results of the negotiations? Third, what conclusions with regard to the theory of cross-border trade in business services can be drawn?

\footnotetext{
${ }^{2}$ All statistical figures based in Singapore are gathered and further elaborated from the website of Singapore's national statistics agency, www.singstat.gov.sg, and specifically from Singapore's International Trade in Services 2014. Statistics based in EU are from Eurostat database, http://ec.europa.eu and from DG Trade.
} 
This agreement can also pave the way for a revitalisation of the interregional EUASEAN talks, in which issues related to services were among the most controversial topics during the times of active negotiations (Lindberg and Alvstam 2012b, p. 71ff). It can be seen as a test of the EU's 'Global Europe' initiative, launched in 2006, and its follow-up communications from the Commission, the latest effort of which, the 'Tradefor-All' in October 2015 (Ahnlid et al. 2011, p. 420f; European Commission 2015b). Furthermore, the global context of parallel and overlapping current interregional negotiations or proposed talks, e.g. TPP, TTIP, FTAAP and RCEP, ${ }^{3}$ should be taken into consideration. Thus, the first part of the paper focuses on the larger trade policy picture, and on the institutional framework of international trade in business services, with a focus on the EUSFTA. The second part takes the firm-level approach, by investigating the already reached as well as the potential future impacts by the actors at both sides of the agreement, and relates in this respect to the ongoing positioning of Singapore as an important service hub within the knowledge-intensive business services in East and Southeast Asia, attracting FDI from the global and regional markets within the larger process of ASEAN integration within the services sector (Chia 2011; Dee 2010, 2012; Findlay 2011; Fink 2008; Fink and Molinuevo 2008; Hamanaka 2011a, b, 2014; Ishido 2011; Ishido and Fukunaga 2012; Kuroiwa and Kumagai 2011; Roy 2012; Ström 2006).

There have been relatively few studies aiming at investigating the impact of regional economic integration at the company level. The, to our knowledge, most comprehensive and successful attempt in this direction was made by the Asian Development Bank Institute, which collected detailed information in a major survey during 2007-2009, resulting in a database of over 800 manufacturing export companies in East Asia (Kawai and Wignaraja 2011b). Further surveys during 2011-2012 expanded the database to include over 1000 firms and concluded that one third of them were using the available FTA preferences (Kawai and Wignaraja 2013, p. 20). The results from the ADBI study have been used as a natural platform for this paper. It should be noted, however, that their work was primarily focused on manufacturing companies, while our study emphasises effects on service companies with in many respects different kinds of trade barriers.

The authors have conducted a number of interviews with the parties in the EUASEAN, respectively EU-Singapore negotiations in order to identify core differences and priorities between stakeholders. The focus of the interviews was to explore how these differences align with the perceptions of these differences among parties concerned in the business sector, and to relate these different positions to the larger regulatory and institutional framework of service markets in ASEAN in general and Singapore in particular. The interviews took place over a long time period, mainly between 2010 and 2014, and covered the EU delegations in four ASEAN countries and trade ministry officials from respective country. Previously, similar interviews had also been conducted in both Brussels and Southeast Asia in connection with research regarding the EU-ASEAN negotiations during the period 2007-2009 (Lindberg and Alvstam 2009, 2012a, b). Personal interviews with companies from Europe, mainly from Sweden and Finland, representing different service sectors, have taken place at various occasions between 2007 and 2014 (see details in Appendix).

\footnotetext{
${ }^{3}$ See further description of these arrangements in the following section.
} 


\section{The larger trade policy picture}

Whereas the multilateral trade negotiations within the framework of the DDA have been trapped in a closed to deadlock situation for a number of years, various forms of regional and bilateral preferential trade agreements have mushroomed in all parts of the world. The conclusion of regional and bilateral trade agreements (RTAs and BTAs) are traditionally considered to be a less efficient strategy for trade liberalisation, and are still disputed in the theory of customs unions (Wong 2006). Compared with the multilateral order, they are often accused for undermining the system itself, and are sometimes labelled 'spaghetti bowls' or 'noodle soups', due to the large number of confusing, complex and overlapping country-to-country constellations (Kuroda 2006; Bhagwati 2008). However, for the time being, they are here to stay, and the issue is now rather how to make them more compatible with multilateral rules (Baldwin 2006; Hufbauer and Schott 2009; Baldwin and Thornton 2008; Baldwin and Low 2009; Rizwanul Islam and Alam 2009; Hillman 2010; Wignaraja and Lazaro 2010; WTO 2011; Lindberg and Alvstam 2012a). Many of the outstanding issues in the delayed DDA talks are related to the service sector, which has a much shorter history of being negotiated at the multilateral level than manufacturing. It was not until the conclusion of the Uruguay round within the GATT agreement and the inauguration of the WTO that services in general were incorporated under the multilateral umbrella, operationally through the GATS (Marchetti and Mavroidis 2011). Both RTAs and BTAs are allowed for by the WTO under certain conditions. The guidelines are given in GATT's Article XXIV, GATS' Article V and the so-called Enabling Clause. GATS' Article V states that a regional or bilateral agreement in services must have substantial sectorial coverage (in terms of number of sectors, volume of trade affected and modes of supply) and provide for the absence or elimination of substantially all discrimination between or among the parties involved. In addition, the general GATS' articles, e.g. regarding MFN status (Art. II), Transparency (Art. III) and Market access (Art. XVI), apply. It has to be kept in mind that the EU Services Directive (Dir. 2006/123(EC)), which regulates the trade in services between the member states, is generally more far-reaching than the GATS, and obstructs in this respect the MFN principle, although this issue is addressed through Article V.

Despite more than 15 years of implementation of the GATS, the outcome has so far been modest. There is still a lack of common definitions and categorisations of certain elements in the service trade, particularly how to measure and apply rules of origin, how to account for value added of service inputs when services are embedded in the physical products, and how to delimit services within a larger context of elements in a general Preferential Trade Agreement. ${ }^{4}$ Furthermore, there are a number of issues where the GATS until now has not reached the initial ambitions to facilitate crossborder services transactions, such as public procurement, subsidies, labour mobility, and problems related to different competition policies. The plurilateral initiative in 2012

\footnotetext{
${ }^{4}$ The most comprehensive documentation of applied multilateral rules in the statistical reporting of international trade in services can be found in the Manual on Statistics of International Trade in Services 2010, published by the Statistical Commission of the United Nations (MSITS 2010); see also the manuals on Balance of Payments (BOP) 2008, and System of National Accounts (SNA) 2009 for the basic statistical classifications related to the service sector, and the GATS' classification list for services, MTN.GNS/W/120 of 10 July 1991, available at http://www.wto.org/english/tratop_e/serv_e/serv_e.htm.
} 
to launch the TiSA, incorporating the largest countries in international trade in general and trade in services in particular can be seen as an action to push the services agenda further. While both the EU and the USA are actively involved in these talks, Singapore is not. ${ }^{5}$

There has, apart from TiSA, been a period of several parallel initiatives at the global level as well as between the members of the 'Asia-Pacific Economic Cooperation' (APEC) to launch and to accelerate broad trade and investment agreements aiming further than what can be reached within the WTO framework. ${ }^{6}$ Both the EU and Singapore are deeply involved in larger ventures. This raises the question regarding the long-term ultimate priorities of both parties. Singapore is one of twelve members of the recently concluded, though not yet ratified nor implemented 'Trans-Pacific Partnership' (TPP), which has been seen as the top trade political priority from the US perspective, while the EU and the US are at the same time negotiating a 'Transatlantic Trade and Investment Partnership (TTIP), also a main pillar in the external economic relations of both parties. Since Mainland China is not a TPP partner, it has on its part re-launched an old idea (Bergsten 2007) of a 'Free Trade Area of Asia and the Pacific' (FTAAP), incorporating initially the 'ASEAN $+6,{ }^{7}$ but in its extension virtually the whole 21 member APEC plus South Asia. In addition, the ten ASEAN members launched in 2012 the idea of a 'Regional Comprehensive Economic Partnership' (RCEP) in order to consolidate all ASEAN +1 FTAs with six countries in the region, i.e. in reality to create an ASEAN + 6 framework. It is also both in China's and the ASEAN members' joint interest to calibrate and harmonise new agreements with the existing ACFTA (ASEAN-China FTA) framework. In addition, there are more than 50 existing bilateral agreements in the form of FTAs and more comprehensive Economic Partnership Agreements (EPAs) among the APEC members. In an effort to stress the unity of the member states, China's President Xi Jinping emphasised already at the annual APEC meeting in November 2014 that an FTAAP 'does not go against existing free-trade arrangements in the region', and should rather be seen as an 'aggregation' of these arrangements. ${ }^{8}$ The FTAAP initiative as the major instrument to further APEC's regional economic integration agenda was reconfirmed in the 2015 annual meeting, while the finalisation of the TPP negotiations as a 'possible pathway' to the FTAAP was 'noted', and the early completion of RCEP negotiations was 'encouraged' in the 23rd Leaders’ Declaration (www.apec.org. 2015 Leaders’ Declaration. Manila, 19 November 2015). It is widely agreed that interregional as well as regional preferential trade agreements would improve and consolidate the increasing importance of Asian countries in ever more tightly connected global and regional

\footnotetext{
${ }^{5}$ At the time of writing (October 2016), 23 parties are involved in the ongoing negotiations, representing $70 \%$ of world service trade. Since the European Union itself represents 28 member states, the initiative covers 50 WTO members (European Commission, Directorate-General for Trade 2016a, b, c).

${ }^{6}$ APEC can, despite the fact that it has no role as a formal negotiation body, be seen as an important 'testing ground' for initiatives that later can be brought forward in other fora. Its Business Advisory Council offers moreover a natural platform for interaction between policymakers and MNEs. APEC also includes a couple of actors, e.g. Hong Kong SAR and Taiwan (Chinese Taipei) that are not formal participants in other regional talks. Taiwan is, though, participant in a number of BTAs, including with Singapore.

${ }^{7}$ The ten ASEAN members plus Mainland China, Japan, South Korea, Australia, New Zealand and India.

${ }^{8}$ When speaking at the dialogue between the APEC leaders and representatives of the APEC Business Advisory Council. http://news.xinhuanet.com/english/china/2014-11/10/c_133779321.htm, 10 November 2014.
} 
production networks in a number of advanced manufacturing industries, e.g. automotive, telecommunications, electronics and pharmaceuticals, all comprising increasing levels of embedded service value added, arisen within ASEAN, as well as in the East Asian region as a whole (Athukorala 2011; François and Wignaraja 2008; Hiratsuka 2011; Hufbauer and Schott 2009; Kawai and Wignaraja 2011a, b, 2013; WTO 2011). From this theoretical starting point, all initiatives should be seen as positive steps, although complex 'PTA competition' between various, often overlapping country constellations may at the same time become a hurdle in itself towards the widely accepted need for further trade liberalisation, not least in the services sector.

One outstanding issue from the very beginning of the BTA negotiations with Singapore was whether other ASEAN states would follow suit, and, in such a case, in which sequence? Malaysia and Vietnam were those countries that already in 2009 commenced preliminary talks in the form of 'scoping exercises'. Formal negotiations with Malaysia were launched in October 2010 and with Vietnam in June 2012. ${ }^{9}$ Malaysia has been the obvious second runner after Singapore, since it ranks second in terms of the turnover value of goods and services and enjoys in many sectors free access to Singapore, but maintains relatively high tariff rates and keeps a complex tariff schedule (Drzeniek Hanouz and Geiger 2010, p. 38). These negotiations have, however, not proceeded along with the expected timetable and were put on hold in April 2012 at Malaysia's request. Vietnam, on the other hand, was expected to lag behind, despite vast improvements in the trade environment, not least due to the recent WTO accession, which led to significant liberalisation of trade in goods and services over the phase-in period to 2012 (Drzeniek Hanouz and Geiger 2010, p. 46), but turned out to be a more ambitious partner, and the negotiations were concluded in December 2015. Pending Council decision and EU Parliament consent early 2017, it is expected that the agreement can enter into force in 2018. After a scoping exercise with Thailand, formal negotiations were launched in March 2013 (see footnote 11), but have, similarly to Malaysia, been brought to a 'pause'. The last round so far took place in April 2014. Negotiations with the Philippines were launched in December 2015 with a first round in May 2016. The first round with Indonesia took place in September 2016. The ultimate ambition from the EU side has been to integrate the coming bilateral deals into an interregional trade agreement, according to the initial ambitions from 2006. One of the problems related to the 2007-2009 talks regarding the political concerns with individual ASEAN members, notably Burma/Myanmar, leading to the 'ASEAN minus X' debate (Lindberg and Alvstam 2012b), may have become less sensitive with the opening up of a reform process in the country since 2011 . The ambition to resume an interregional agreement with the entire ASEAN was further emphasised in the communication 'Trade-for-All' (European Commission 2015b, p. 31f).

The UK initiation of leaving the EU, following the referendum in June 2016, will have both a direct and an indirect impact on the EUSFTA. Before the UK's formal exit, expected to take place in 2019-2020 at the earliest, the country remains within not only this agreement, but within all other ongoing EUSFTA negotiations with Asian countries as well as in the current TTIP talks. Even though the UK will still remain within the union for the immediate years, and will also not be able to initiate any separate formal

\footnotetext{
${ }^{9}$ For further reference, see the updated list of the current situation regarding EU's Free Trade Agreements, http://trade.ec.europa.eu/doclib/docs/2006/december/tradoc_118238.pdf (accessed 4 October 2016).
} 
bilateral FTA talks with any partner before it legally leaves, it is reasonable to expect that its future exit will indirectly have an impact on all current EU negotiations, in which the respective counterparts will assess potential benefits and shortcomings of an agreement in which UK will not participate.

In summary, the EU-Singapore FTA should be viewed in a larger global and regional trade policy context. Its future realisation will be directly related to two main scenarios: First, in a situation when the TPP and/or TTIP might fail to be concluded in the near future, and the FTAAP/RCEP initiatives still reflect long-term ambitions rather than short-term action, the EUSFTA can function as a miniature role model of how a comprehensive trade and investment partnership can be designed at a larger scale, e.g. in an interregional agreement between the EU and ASEAN. Second, if the TPP and TTIP negotiations will eventually be successfully finalised, the main ambition of an EUSFTA will be to secure that this agreement is not only equalling the standards of TPP and TTIP, but that it also should aim at proceeding further beyond a 'WTO-Plus' framework.

\section{EU-ASEAN trade relations and ASEAN trade in goods and services}

Despite a rapid pace of growth of trade between the EU and the ten ASEAN members, in goods as well as in services, over the last decade, the relative importance of the economic relations between the EU and ASEAN, measured in terms of shares of world trade values, has deteriorated or stagnated (Tables 1 and 2). Seen in the longer time perspective, after the Asian financial crisis in the late 1990s, the initial even balance of trade in goods between the two parties changed into a growing trade deficit, seen from the EU perspective, caused by stagnating and declining exports of the EU to ASEAN countries as an effect of currency depreciations among several member states and the need to reduce budget deficits in the region. This imbalance has not been restored thereafter. The relative decline of the EU-ASEAN trade relations is in the first place a reflection of the higher pace of growth in intra-ASEAN trade, as well as the intensified economic relations between the ASEAN countries and other states in the Asian realm, with the exception of Japan. Mainland China has in recent years replaced Japan as the

Table 1 The relative importance of EU-ASEAN trade in goods 2005-2014 (percentages)

\begin{tabular}{lrrrrrrrrrr}
\hline & 2005 & 2006 & 2007 & 2008 & 2009 & 2010 & 2011 & 2012 & 2013 & 2014 \\
\hline Share of EU in ASEAN exports & 12.7 & 12.8 & 12.7 & 11.9 & 11.5 & 11.1 & 10.7 & 10.1 & 9.9 & 10.3 \\
Share of EU in ASEAN imports & 10.3 & 10.1 & 10.7 & 9.9 & 10.8 & 9.4 & 9.5 & 9.7 & 9.8 & 9.3 \\
Share of EU in ASEAN trade & 11.6 & 11.6 & 11.7 & 10.9 & 11.2 & 10.3 & 10.1 & 9.9 & 9.8 & 9.8 \\
Share of ASEAN in EU total exp. & 1.4 & 1.3 & 1.4 & 1.4 & 1.5 & 1.5 & 1.5 & 1.7 & 1.7 & 1.6 \\
Share of ASEAN in EU total imp. & 2.3 & 2.1 & 2.0 & 1.9 & 2.0 & 2.1 & 2.1 & 2.2 & 2.1 & 2.2 \\
Share of ASEAN in EU total trade & 1.8 & 1.7 & 1.7 & 1.6 & 1.8 & 1.8 & 1.8 & 1.9 & 1.9 & 1.9 \\
Share of ASEAN in EU extra exp. & 4.2 & 4.2 & 4.3 & 4.3 & 4.6 & 4.6 & 4.4 & 4.9 & 4.6 & 4.6 \\
Share of ASEAN in EU extra imp. & 6.1 & 5.6 & 5.6 & 5.0 & 5.5 & 5.7 & 5.5 & 5.6 & 5.8 & 6.2 \\
Share of ASEAN in EU extra trade & 5.2 & 5.0 & 5.0 & 4.7 & 5.1 & 5.2 & 5.0 & 5.3 & 5.2 & 5.4
\end{tabular}

Source: Elaborated from IMF DOTS Database, November 11, 2014; DOTS Quarterly, December 2015 
Table 2 The relative importance of EU-ASEAN trade in services 2005-2014 (percentages)

\begin{tabular}{lrrrrrrrrrr}
\hline & 2005 & 2006 & 2007 & 2008 & 2009 & 2010 & 2011 & 2012 & 2013 & 2014 \\
\hline Share of EU in ASEAN exports & 11.9 & 11.4 & 10.0 & 9.8 & 9.9 & 9.3 & 9.8 & 9.7 & 9.6 & 9.8 \\
Share of EU in ASEAN imports & 10.9 & 11.4 & 11.6 & 10.1 & 11.4 & 10.7 & 9.7 & 9.3 & 10.6 & 11.5 \\
Share of EU in ASEAN trade & 11.4 & 11.4 & 10.8 & 10.0 & 10.7 & 10.0 & 9.8 & 9.5 & 10.1 & 10.6 \\
Share of ASEAN in EU total exp. & 1.6 & 1.7 & 1.9 & 1.8 & 1.9 & 1.8 & 1.9 & 1.8 & 2.1 & 2.1 \\
Share of ASEAN in EU total imp. & 1.6 & 1.7 & 1.7 & 1.8 & 1.8 & 1.7 & 2.1 & 2.1 & 2.2 & 2.1 \\
Share of ASEAN in EU total trade & 1.6 & 1.7 & 1.8 & 1.8 & 1.8 & 1.8 & 2.0 & 2.0 & 2.2 & 2.1 \\
Share of ASEAN in EU extra exp. & 3.9 & 4.1 & 4.4 & 4.2 & 4.3 & 4.2 & 4.2 & 4.0 & 4.6 & 4.7 \\
Share of ASEAN in EU extra imp. & 4.1 & 4.3 & 4.3 & 4.4 & 4.3 & 4.8 & 5.0 & 4.0 & 4.0 & 3.9 \\
Share of ASEAN in EU extra trade & 4.0 & 4.2 & 4.3 & 4.3 & 4.3 & 4.5 & 4.6 & 4.0 & 4.3 & 4.3 \\
\hline
\end{tabular}

Source: Elaborated from Eurostat database, http://epp.eurostat.ec.europa.eu; accessed 9 February 2016; ASEANStats Database, accessed 9 February 2016. Figures regarding Brunei, Laos and Vietnam have been estimated. EU mirror data have been used to calculate the shares of total ASEAN service trade

main trading partner of ASEAN and is expected to consolidate this position even more in the near future. The trend of stagnating or decreasing shares in the EU trade is typical for other parts of Asia as well. The colonial legacy of a close network of business relations, often emanating from the demand of tropical natural resources and an asymmetric exchange of raw materials with final consumer goods, is thus since long a memory of the past, although the UK and the Netherlands do still account for the lion's share of the EU's total trade relations with South and Southeast Asia. The UK was the dominant trade partner to Singapore in the past, and accounted for about $30 \%$ of the total turnover in trade in goods in 1975, but its share has 40 years later declined to about $13 \%$, with a particularly sharp decrease of the shares in UK exports to Singapore. In terms of values, these flows have subsequently been surpassed by Germany, the Netherlands, France and Belgium in recent years. The previous bilateral surplus between the UK and Singapore as late as 10 years ago has shifted to a deficit. The export/import ratio in 2014 amounted to 0.75 (IMF 2016b).

Instead the main new feature in the external trade pattern, intra- as well as interregionally, has been the emergence of complex networks of highly specialised and spatially dispersed production of semi-manufactured inputs, parts and components, resulting in what is usually labelled 'intermediate trade'. A recent estimate shows that the intermediate trade accounts for about $60 \%$ of global trade values (UNCTAD 2013, p. 122). Depending on various statistical definitions of these transactions, this figure varies. A broader definition would presumably result in even higher shares. One phenomenon within the larger context of intermediate trade is the growing significance of 'intra-industry trade', representing exchange of goods and services within identical or almost identical categories. Intermediate and intra-industry trade can be observed within 'intra-firm', as well as 'inter-firm' networks, where the rising trend towards increasing shares of intra-firm trade, operated within transnational corporations, has recently been challenged by the parallel trend towards outsourcing and offshoring of separate elements in the global value chain - GVC (Feenstra 1998; Gereffi et al. 2005; Johnson and Noguera 2012; UNCTAD 2013). The EU represents a case with a higher share of foreign value added in exports, compared to the global level- $39 \%$ and $28 \%$, 
respectively (UNCTAD 2013, p. 127, 2010 figures), while Singapore is an example of an extremely high GVC participation rate- $82 \%$ of Singapore's export is related to a global multi-stage process, compared with $64 \%$ in Germany and $45 \%$ in the USA (UNCTAD 2013, p. 132). ${ }^{10}$ When it comes to the trade measured by the value added, which gives a better picture of the actual participation of a country in the larger global value chain than the traditional gross value measure, it is notable that the UK share of Singapore's trade in services with the EU has increased between 1995 and 2011 (OECD-WTO 2016). This observation indicates that the role of British service firms in the Singaporean relations with the EU is still strong.

In this context, the value added of services is normally either embedded into the larger sector of manufacturing production and trade in goods, or exhibited as a separate sector of service production and exports. This ambiguity has always been a matter of concern in the analysis of the role of services in the multilateral trade order, despite decades of attempts to find and adopt a universally accepted solution. In the meanwhile, the value added of pure services as a share of the gross output value of physical production has continued to rise, at the same time as there has also been a major global shift of the geographical location of services value added from Europe and North America in the direction of Asia, although with a time-lag compared with the similar development regarding the manufacturing value added. The share of foreign valueadded exports in the services sectors is normally much lower than in manufacturing (UNCTAD 2013, p. 128). ${ }^{11}$ There has in general terms been a shift from low- to highvalue-added service sectors in the EU-ASEAN trade, e.g. from transport and storage to a complex mix of advanced professional business services. This is an area of particular importance and strength for the UK economy, where several firms are using Singapore as an important location for East and Southeast Asia.

While the EU-ASEAN bilateral trade in goods is characterised by a deficit as seen from the EU perspective, the reverse situation is typical in the field of services. The merchandise accounts for about $80 \%$ of the total bilateral trade turnover of goods and services. The export/import ratio regarding goods between the EU and ASEAN was in average 0.74 during the period 2010/2014, representing an annual average EU deficit of about 32 billion USD. The corresponding ratio in the field of services was at the same time 1.1, representing an EU surplus at about 3 billion USD/year in absolute terms. There is from the ASEAN perspective a slow but steady declining EU importance also in the service sector, while the shares of ASEAN in the total EU trade in services show a slight growth, although from a much lower level (Table 2). This trend is in the statistical reporting not incorporating the value-added in services embedded in predominant manufacturing companies, why the 'real' service value-added presumably has grown at an even higher pace.

Being the economically largest member state of ASEAN, Singapore's own development is crucial for the entire region. Between $35 \%$ and $40 \%$ of EU's exports of goods

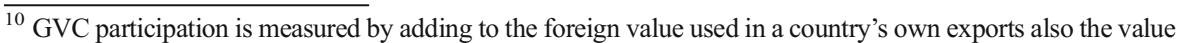
added supplied to other countries' exports. The sum is divided by total export value. This quota can further be disaggregated in an upstream and downstream component, respectively, indicating whether domestic producers of value added are situated late vs. early in the global value chain. The concept was developed in Koopman et al. (2011).

${ }^{11}$ According to the UNCTAD study, the share of foreign value added in the tertiary sector was $14 \%$, compared with $29 \%$ in the secondary sector (UNCTAD 2013, p. 128)-2010 figures.
} 
to ASEAN has been reported with Singapore as country of destination during the last 10 years, while the corresponding share of Singaporean origin of imports from ASEAN to the EU has varied between $20 \%$ and $25 \%$. There is a slight, although clearly visible trend that Singapore's share is about to decline, which is a natural effect of the ambitions of other member states to take a more direct position in the interregional trade with Europe and North America. However, this trend is more typical for the manufacturing sector rather than in services, where Singapore still keeps a strong lead.

Singapore accounts at present for $40-45 \%$ of the total ASEAN imports and exports respectively of commercial services, and its position has furthermore become stronger during the past decade. Singapore's service balance has varied considerably over the years. There was a strong tendency towards a growing surplus during the 10 years from the mid-1980s to the mid-1990s, followed by a long period of diminishing of the gap and a couple of years in the 2000s until 2009 when a deficit was accounted. During the last years a modest deficit has been reported. The other major ASEAN countries show normally negative service balances, with a particularly widening deficit in Thailand.

The EU share of Singapore's trade in services has remained stable during the last 10 years with around 13-16\% of the total services trade (Table 3). In absolute figures, there has since 2010 been a small deficit, as viewed from the Singaporean side, with an export/import ratio with the EU amounting to about 0.97 (2014).

A categorisation of the sub-groups in Singapore's total trade in services when it comes to the change of relative importance in 2005/2009 compared with 2010/2014, as well as their cumulated surplus or deficit during 2005-2014, is featured in Fig. 1. ${ }^{12}$ The three largest categories, 'Transport', 'Travel' and 'Other Business Services' represent together $72 \%$ of total service trade in $2010 / 2014$, compared to $75 \%$ in $2005 / 2009$. The main reason for the decline is the decreased importance of transport services, while the other groups have grown in relative terms. On the other hand, the transport sector generates a surplus, which the two other main sectors do not. The next two important sectors are financial services and charges for the use of intellectual property. Both are increasing in importance, but where trade in financial services generates a large surplus, the IPR charges give rise to a huge deficit. The large group 'Other business services' can further be disaggregated in sub-groups (Fig. 2), in which it is revealed that the dominant group 'Business management' generates the largest cumulated surplus between 2005 and 2014 and is also growing in importance, while trade-related business services and R\&D related services account for large deficits. A similar picture of the cumulated balance between Singapore and EU with a different classification and primary data is exhibited in Table 4.

Within ASEAN as a whole, there are striking differences between countries as well as between exports and imports. ASEAN reports a large deficit in transport services, a surplus in travel and a deficit in other commercial services. While Singapore, as was mentioned above, accounts for a robust surplus in maintenance and repair services, transport, finance, business management, accounting, advertising/market research,

\footnotetext{
${ }^{12}$ Due to differences in the compilation of primary sources, generally between survey and administrative data, and also between different methods and classification categories in the conducted surveys, there are slight differences between various secondary data publications and databases by the Department of Statistics. This paper has used a mix of data presented in Singapore's International Trade in Services, 2014, and the statistical tables derived from the tablebuilder database; see further the technical notes in SITS 2014:15ff and www. singstat.gov.sg; special survey.
} 
Table 3 The relative importance of Singapore-EU trade in services 2005-2014 (percentages)

\begin{tabular}{lllllllllll}
\hline & 2005 & 2006 & 2007 & 2008 & 2009 & 2010 & 2011 & 2012 & 2013 & 2014 \\
\hline EU's share of Singapore's exports & 13.5 & 14.0 & 14.6 & 16.6 & 16.4 & 15.1 & 15.0 & 13.7 & 14.4 & 13.7 \\
EU's share of Singapore's imports & 14.4 & 16.4 & 14.7 & 16.7 & 15.4 & 16.4 & 16.7 & 16.0 & 17.8 & 15.9 \\
\hline
\end{tabular}

Source: Elaborated from Singapore's international trade in services tablebuilder: www.singstat.gov.sg; accessed 9 February 2016

Note: There are slight differences between secondary data sources, due to different compilation methods, see also footnote 15

architectural, engineering/technical and legal services, and reports a huge deficit in IPRrelated payments, travel, insurance, $R \& D$ and trade-related services, Thailand on the other hand reports a considerable surplus in travel services that does not compensate for the vast deficits in transport and other commercial services. A similar picture is shown in the case of Malaysia. There is, accordingly, a high degree of complementarity between Singapore and its ASEAN neighbours when it comes to trade in services. This complementarity is partly created through Singapore's sometimes self-imposed role of being the hub for advanced business services in Southeast Asia, but it does also reflect the potential of a deeper division of labour within ASEAN member states, and the opportunities to resume the interregional EU-ASEAN FTA talks, when the 'pilot cases' of Singapore and Vietnam are to be implemented.

\section{Singapore as a service hub in Asia}

As part of the strategy to connect to the global market through free trade and FDI, the Singaporean government has put extensive effort into building a foundation for a knowledge-based economy. The economic transformation has accelerated over the last decades, by moving from a manufacturing-based to a service-based economy. The Singapore case shows the importance of the service economy for emerging markets in order to increase their competitiveness and welfare creation (World Bank 2012). The strategy has involved upgrading the local economy by strengthening the human capital through continuous investments in education. The awareness of the importance of highly educated human capital for the development of high order services has put Singapore ahead of many other emerging markets (Jensen 2013). The aim has also been to enhance the possibility for value creation and the connection of advanced manufacturing and services, which is an important part of connecting to global and regional production networks (Shepherd and Pasadilla 2012). Industries, such as advanced information technology, telecom, biotech and potential green application of advanced manufacturing and service production, are all important sectors for the future (Masuyama and Vandenbrink 2003; Ström 2006; Aldaba and Pasadilla 2010). These industries are furthermore supported by Singapore's highly developed and efficient transportation and logistics services that, by themselves, are also key drivers of economic integration (Fujita et al. 2011, p. 3).

The positive attitude towards creating better opportunities for service trade and FDI is well in line with Singapore's long-term strategy. The aim has been to become a 


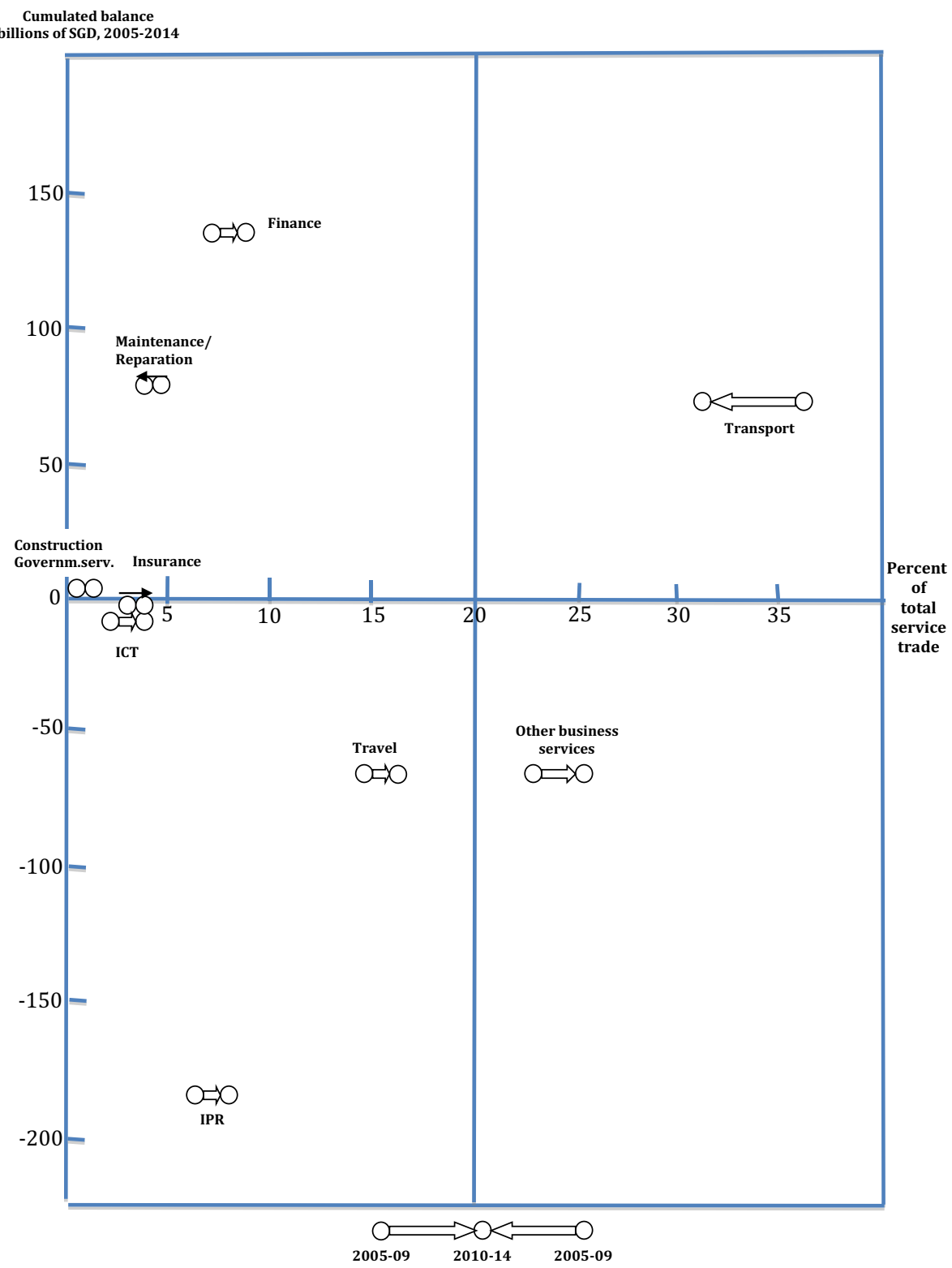

Source: Authors' elaborations, based on official Singaporean trade statistics

Fig. 1 Singapore's trade balance and development of shares of total service trade with EU28 between all subsectors of services 2005-2014

knowledge and service hub in Southeast Asia (Ström 2006). Singapore is one of the forerunners within Southeast Asia to acknowledge the importance of the service industry for creating sustained economic growth. In this context, many countries in Asia have mainly been focusing on facilitating the manufacturing side of the economy, and the potential of services has been left out in developing market integration. Productivity within the service industry has also been lower compared with 
Cumulated balance

billions of SGD, 2005-14

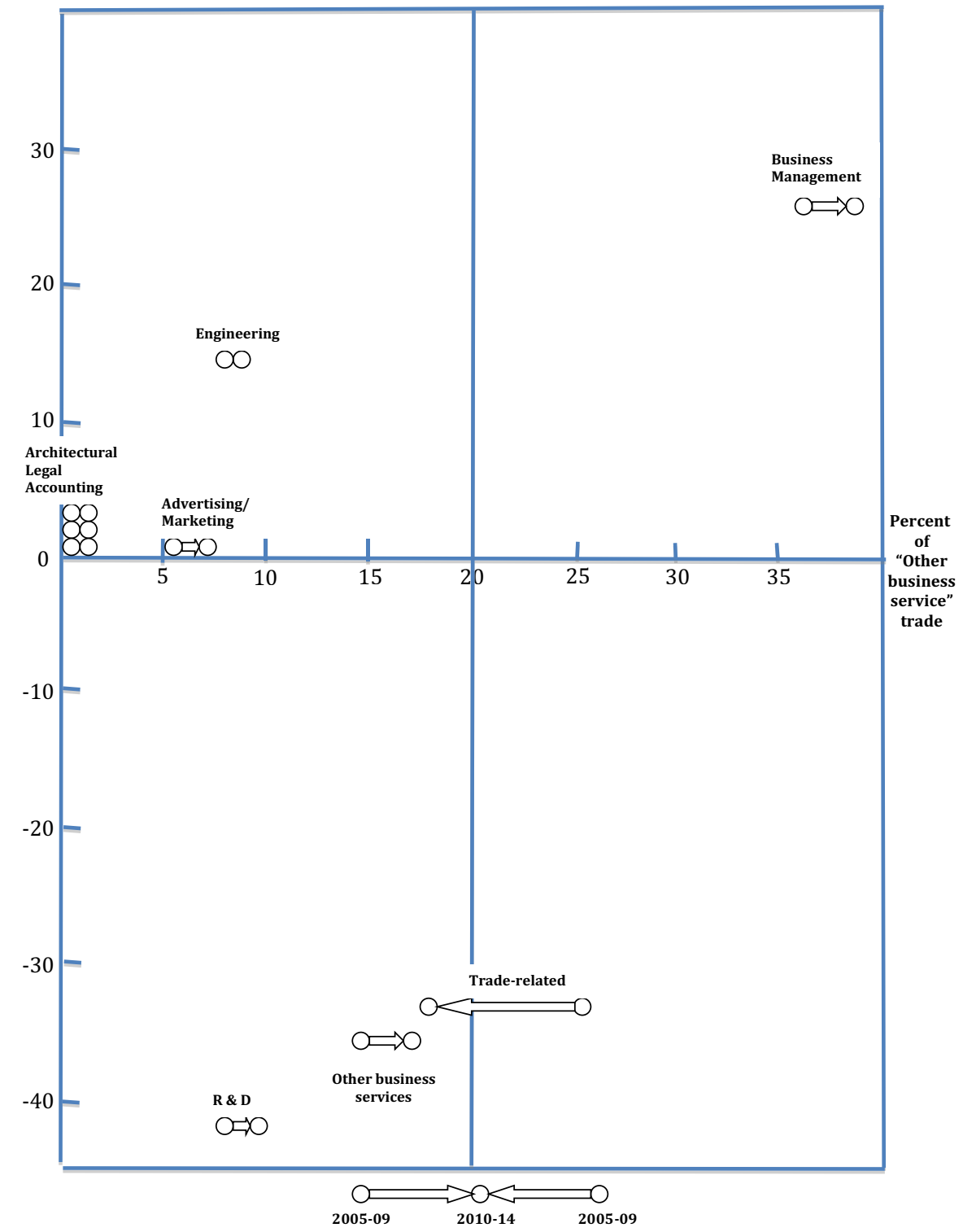

Source: Authors' elaborations, based on official Singaporean trade statistics

Fig. 2 Singapore's service trade balance and development of shares of total service trade with EU28 between sub-sectors of 'Other Business Services', 2005-2014

manufacturing in Asia, and it is a potential to utilise the growth of services to offset the loss of momentum for the manufacturing industry (Noland et al. 2012). The free market and open attitude has attracted FDI in many different sectors. Singapore has become an important regional hub for services in general and knowledge-intensive business services in particular. The latter includes various financial services that have become an integral part of the economy for supporting economic integration in the region 


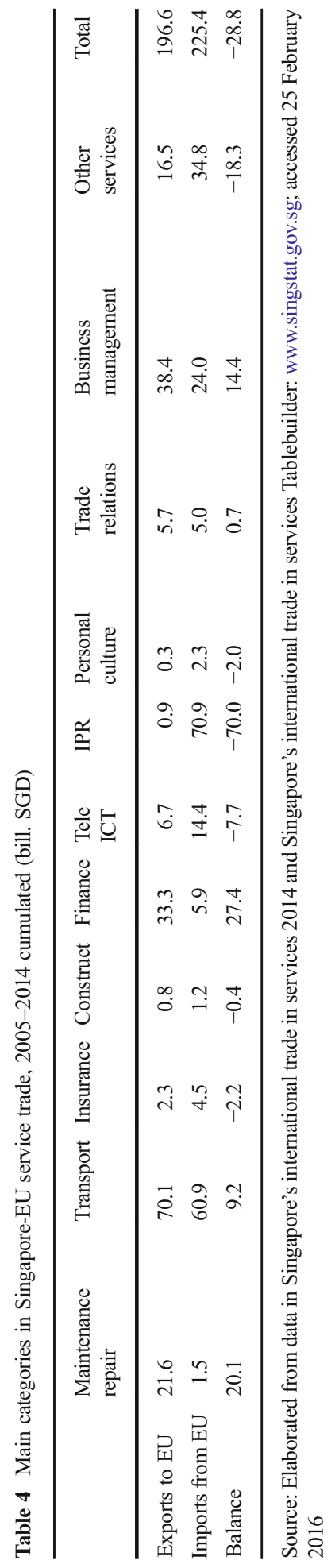


(Ström and Yoshino 2009). Some of the firms in financial services have also grown to be among the largest companies in ASEAN, such as three Singaporean banks that are second only to Singapore Telecommunications by market capitalisation (ASEAN Investment Report 2015, p. xviii). The strategy to establish Singapore as a service and knowledge hub involves different parts. One of the most fundamental aspects is to offer a well-functioning regulatory environment that facilitates and protects knowledge IPR. This has proven to be an important factor for attracting new types of firms where the business models are mainly based on different Internet applications.

The geographic location in the region has also endowed Singapore with a competitive advantage, creating a centre point for business venturing out to surrounding part of ASEAN. However, with the growth of China and the rise of other knowledge and service hubs, such as Shanghai, Beijing and Hong Kong, the Singaporean strategy is challenged (Yeh and Yang 2013). With increasing business activity in North East Asia, it has been evident for Singapore that the government needs to work even harder in order to continuously attract regional headquarters of MNEs from Asia, Europe and North America and facilitate the development of knowledge-intensive service industries.

Singapore has been highly successful in attracting investments from MNEs in the region, mainly from Japan, but also from the US and Europe. The open environment has also attracted firms to utilise Singapore as a service hub for the region. Originating from the most developed country in East Asia, Japanese investments in regional production networks and financing have been one of the most important growth facilitators. At an early stage, Singapore became a vital hub in Southeast Asia for Japanese investments in manufacturing and trading activities, and has later developed into a major hub also for Japanese service investments and localisation of company operations (Hamanaka 2011a, b). Singapore's free-trade agreement with Japan has further facilitated this growth in service FDI. Empirical studies of Japanese service FDI clearly show the importance of the combination of location and institutional or regulatory environment for the choice of Singapore. Companies with the knowledgeintensive service industry state that Singapore is an attractive location for developing and supporting the client base in the region (Ström 2006; Ström and Yoshino 2009). However, with an increasing liberalisation of service trade and the move of production networks to China, they also see Hong Kong and Shanghai as potential competitors. When firms evaluated a second regional base outside Japan, the choice was often Singapore or Hong Kong due to the favourable institutional environment. It is in this larger context that the recently concluded EU-Singapore FTA negotiations should be assessed and evaluated.

\section{The EU-Singapore free-trade negotiations and related development in the region}

Shortly after the parties in the EU-ASEAN FTA negotiations agreed to take a pause in 2009 , the original two-year-deadline for the negotiations was reached. It was time for reflections on and an evaluation of the achievements made so far, not only for the EUASEAN process, but also for all the FTA negotiations that had been launched in 2007. It was then concluded that alternative routes were necessary, since the region-to-region process had not delivered. Hence, it was agreed that the EU would now be ready to 
engage in bilateral negotiations with individual ASEAN members, as long as their level of ambition matched that of the EU.

The EU member states gave therefore in December 2009 the Commission green light to pursue negotiations towards BTAs with individual countries, starting with Singapore (Press release from the European Commission, DG Trade, 22 December 2009 (http://trade.ec.europa.eu/doclib/press/index.cfm?id=504). The first round of negotiations took place in March 2010, with the ambition to conclude them by mid2011. This 'pilot' BTA initiative has served as a good first example of how the two regions could be more closely related, and to keep the door open to a renewed comprehensive region-to-region agreement in the future. It shall furthermore be seen in the light of the trade agreements Singapore has been developing with e.g. China, Japan and the US, both as a separate nation and, in the cases of China and Japan, also within the framework of ASEAN. It was furthermore important for the EU to show the commitment towards Singapore, being an important regional hub for trade and production of goods and services. The issue of the growing importance for trade with China within the ASEAN region and the establishment of the ACFTA, as well as Singapore's participation in the TPP, further strengthened the incentive from the EU side to engage in trade talks to secure a favourable position for European firms in the region. The characteristic feature of the Singaporean economy is its low formal barriers to trade, its role as an entrepôt point for East and Southeast Asia as a whole, its continuous upgrading of domestic production to contain ever higher value-added of manufacturing as well as service inputs, and its high pace of economic transformation in general. The trade-weighted applied tariff rate amounts to almost zero (Drzeniek Hanouz and Geiger 2010 , p. 42). The Singaporean government and related agencies have worked hard during the last decade to develop and establish the city state as an important knowledge and service hub in Southeast Asia, making use of the liberal attitude towards free trade and FDI (Masuyama and Vandenbrink 2003; Hamanaka 2011a, b). Despite these efforts and the high integration ambitions reflected in the ASEAN Economic Community (AEC) 2015 scheme, many technical barriers remain, though, between the member states (Dee 2012; Severino and Menon 2013; Sally 2013; ADB 2014, p. 22ff). There is also a widespread reluctance among Singapore's neighbours to give the island-state an even more dominant role as the business hub for the entire region.

After almost 3 years of negotiations, the two parties completed the deal in December 2012 (Interview with an official at an EU delegation in Singapore, November 2014). It can be seen as one of the most comprehensive FTA that the EU has ever negotiated, and goes in several aspects beyond what is on the table in the DDA process. In particular, this relates to the services sector, such as environmental services, engineering and architectural services, postal services, maritime transport and computer services, but also regarding public procurement and abolition of a number of technical barriers to trade in goods and services, e.g. the mutual recognition of technical and safety standards. In certain fields of financial services, e.g. wealth management, wholesale banking, investment banking and insurance, the results did not reach as far as the EU side had originally aimed at, but the final agreement contains commitments which are at least at the same level as what the US obtained in its FTA with Singapore (Facts and Figures: EU trade agreement with Singapore. Press release 16 December 2012; http://europa.eu/rapid/press-release_MEMO12993 en.htm, accessed on 9 April 2013). The investment talks were concluded in October 2014, thus completing the entire agreement as such. However, a potential obstacle 
regarding the future implementation will be the fact that the entire agreement has been put to the Court of Justice in order to clarify the interpretation of the Lisbon Treaty when it comes to the competence of the Commission and the Council respectively to sign and to ratify an FTA (http://trade.ec.europa.eu/doclib/press/index.cfm?id=1185, 30 October 2014 ). This process may take a considerable time.

\section{Issues related to services in the bilateral negotiations between the EU and ASEAN members}

There have basically been two approaches adopted by leading economies in negotiating services with ASEAN countries, using Singapore as the 'pilot case'. The US approach was to compile a 'negative' list, i.e. to reveal what is not included, while the EU negotiation strategy was to commence from a 'positive' list, i.e. to record what is included, and thereafter gradually approach those sectors where problems remain (Interview with an official at an EU delegation in Southeast Asia, March 2010). Both ways contain advantages and disadvantages. The use of the negative list gives an informal signal to sectors without outstanding problems that actors related to these sectors may continue to implement measures of trade liberalisation without any further delay, and thus speeding up the process. On the other hand, the use of a list of remaining problem sectors could slow down the pace in these sectors, and minor technical issues in peripheral sectors may become hurdles for proceeding with more relevant and wideranging problems. The EU approach on the other hand gives a formal green light case by case to sectors of unanimity, but threatens to put off problem areas to a distant future and thus to defer an ultimate solution. In addition, the EU negotiation strategy to adopt a very ambitious approach along with the idea to conclude 'comprehensive and ambitious third millennium FTAs', as described above, goes in many aspects further than what has been put forward at the multilateral level in the DDA talks, and became in this respect an obstacle itself towards proceeding to the core negotiation agenda in goods and services. Such an approach was disputed also from the EU side (Interview with an official at an EU delegation in Southeast Asia, March 2010. It should be mentioned, though, that the 'negative list' approach was later adopted in the EU negotiations regarding a Comprehensive Economic and Trade Agreement with Canada (CETA)).

The main problem areas can be summarised in, among others, the following categories:

- Adaptation of rules of origin (ROOs) to take the real value added of services input into account;

- Location of service value added; mobility of production and consumption;

- Elimination and/or reduction of technical barriers to trade (TBTs);

- Adjustment of rules related to the international provision of services within the public sector in different countries; government procurement.

\section{Rules of origin}

The traditional operational implementations of ROOs, as they have developed through the common tariff schedules in the multilateral trading system over the years, have been 
to use the shift of statistical classification in the tariff line of a physical commodity to represent a shift of the country of origin. It is at the same time assumed that the shift in commodity classification has been caused by a substantial transformation of the product. Such a method is based on the assumption that the physical product changes its shape in the value-added process. The value added of various forms of service inputs, be they upstream, onstream or downstream, are literally and figuratively much subtler, and more difficult to assess and to measure; accordingly, they are not always resulting in a visible transformation of the product. Subsequently, the value contribution of service inputs is usually underrated in production and trade statistics. ${ }^{13}$ As long as the services value added to the gross value of the product were marginal or modest at best, the problem of changed/unchanged statistical classification did not have any high impact on trade practises by national customs authorities. However, with an increasing share of services in the gross output value of the final physical product, and the pure service product itself, the input of services determines to an increasing extent the country of origin, and, thus, the rules regarding how a certain commodity should be treated. This is particularly the case, now that 'multilateral cumulation', i.e. the compound value added of the final product derived in many countries, has become the normality rather than an exception. Examples of services sectors that are particularly contributing to a 'concealed' value added in physical products are to be found within research and development, IPR charges, design, general management consulting services, quality control and various financial services, but almost all sectors provide cases in the same direction. ${ }^{14}$

Although Singapore is an example of a country with an extremely high degree of trade liberalisation, the issue of how to define Singaporean origin in imports to the EU and other parts of the world, and vice versa, has become a problem. Since a fair share of Singaporean exports in goods as well as in services, consists of products in transit or 'quasi-transit', ${ }^{15}$ it can be assumed that the reported value is biased. This error can, though, arise in both directions, i.e. in either over- or underrating the value of Singaporean exports/imports. In both cases, this causes a problem in the BTA negotiations for a country like Singapore. For other members of ASEAN, the effects may occur in the reverse context, e.g. in such a case when domestic goods from Malaysia is shipped in transit through Singapore with the ensuing confusion regarding the dominant country of origin when the commodity or the service shall be classified at the entry of the EU.

Since the EU has adopted a common external trade policy, operated at the supranational level, and where the concept of external trade between the member states has been replaced by internal 'transactions' within the INTRASTAT framework, the ROO issue is less relevant when it comes to establishing the correct country of origin in

\footnotetext{
${ }^{13}$ See MSITS (2010), for an extensive discussion of these issues.

${ }^{14}$ In extreme cases, the imports to the EU of a seemingly low-cost physical product from Southeast Asia, e.g. a sports shoe, may contain a larger value-added from various service inputs as design, product development etc., derived in Europe than the physical assembly of the product in Southeast Asia. Consequently, the import tariff to the EU, motivated to protect European industry from outside competitors, is calculated from a gross output value that is foremost derived from its own domestic production (National Board of Trade (Sweden) 2011, p. 10).

${ }^{15}$ Defined by when the product in transit undergoes a minor transformation, e.g. re-packaging or re-branding without a shift in statistical classification.
} 
Europe for imports to ASEAN, although it could be subject to different interpretations at different import gateways of the Union. Each member country does still collect and report external trade data for Balance of Payments Statistics purposes. The BOP routine maintains the role of being the main source of service transactions of the EU, intra- as well as extra-regionally (MSITS 2010).

\section{Location of the service value added}

The precise territorial location of value added, and, accordingly, the determination of country of origin in an export transaction, is closely related to the application of rules of origin, as mentioned above. Since statistics regarding trade in services are compiled from companies, whose industry classification belong to the service sector, it is assumed that service production and - trade is related to the formal, registered, location of the surveyed firm. While the statistical bias regarding the location of service value added in the manufacturing sector is related to its 'embeddedness' in the physical production, the main problem in the service production is more connected to the degree of mobility and the spatial flexibility of the service, as seen from both the producers' and the consumers' perspectives. A broad categorisation of various commercial services with regard to the mobility concept can be made from the starting point of the degree of dependence on physical infrastructure, in which tourism, transport, maintenance/repair and trade-related services are related to a higher physical spatial fixture, while most professional business services are not. Accordingly, in the moment when the service is produced and instantly consumed, the consumer has been more likely to cross the national border than the producer. On the other hand, most professional business services are highly mobile, both for producers and consumers, and are in this respect rather subject to legal/formal regulations regarding production and consumption, and in the next step, to cross-border transactions of either the production or the consumption. It is therefore crucial to determine whether the service offered by the foreign firm within the borders, in this case of Singapore, is eligible to national standards or not. These restrictions are usually summarised under the framework of technical barriers to trade.

\section{Technical barriers to trade}

While traditional tariff barriers, as well as non-tariff barriers like import quotas and voluntary exports restraints, have been completely eliminated or substantially reduced within the framework of the multilateral system, a large number of technical barriers to trade still make considerable obstacles to trade liberalisation and are subject to the main attention in the current FTA and EPA talks in different constellations around the world. It could even be argued that TBTs have become even more important trade frictions with the increasing complexities of products, and the introduction of higher ambitions in trade practises, e.g. the imposing by the EU of unconditional demands on standards concerning safety, sanitary/phytosanitary protection, environment, labour, human rights etc. Since the service sector in general is underdeveloped when it comes to globally accepted trade rules and practises, compared with agriculture and manufacturing, services exhibit a large variety of local rules, originally aimed at the domestic market, but which have become subject to interpretation by foreign competitors as a result of 
increasing internationalisation. In the Singaporean case, the most typical examples are to be found in the banking and finance sector, recognition of foreign education, and rules regarding intellectual property rights (Interviews with officials at the EU delegation in Singapore, March 2010 and November 2014). The recent differences between the EU and a number of Asian countries regarding the interpretation of the Information Technology Agreement, adopted by the WTO in 1996, and extended in 2015, is another example of how the measurement of the value of services complicates the operational implementation of rules in international trade practises (WTO 2015a). The ITA has been a pilot landmark agreement in putting together the physical products (hardware) and the intellectual content of information technology products (software) within the same trade policy framework. The two other examples of the plurilateral approach within the WTO are the currently negotiated TiSA, and the Environmental Goods Agreement (EGA).

In the EU context, a union-wide common technical harmonisation and standardisation practice has certainly proceeded successfully during the last 25 years within the general framework of the Single Internal Market, but many issues remain, particularly related to the new member states, but also as a consequence of long traditions of developing national standards and norms among the original members.

Another area that has attracted growing attention recently is the need for further trade facilitation, where the gains from improved quality and reduced time of international transfers are found to be substantial in the particular case of ASEAN (see, e.g. Drzeniek Hanouz and Geiger 2010, p. 13, quoting several studies that confirm the immediate need to carry out trade facilitation reforms in parallel to conventional trade negotiations). This is another example of a problem that is also addressed at the multilateral level, being one of the 'Singapore Issues' defined in the first WTO Ministerial Meeting, held in Singapore, in 1996. The new Trade Facilitation Agreement was adopted by the WTO General Council in 2014 and will come into force when two thirds of the members have accepted it (WTO 2015b). ${ }^{16}$

\section{Government procurement in the service sector}

Government procurement practises can be seen as a special case in the monitoring of technical barriers to trade. Rules and regulations related to public procurement in services, e.g. healthcare, education, military etc., have for a long time been a notable exception to trade liberalisation, and the level of national protection is usually far higher than in the field of private business services. The ambition of the EU has been to incorporate government procurement rules in the RTA/BTA negotiations with other parties in order to open up domestic markets for foreign competition. This ambition has also been in line with the multilateral talks, where global rules regarding government procurement and competition policies in general became also 'Singapore issues' in 1996. The resistance among many countries to extend the GATS to comprise public procurement has been widespread, and this issue has been, at least temporarily, pushed aside in the DDA. The EU ambition, however, is to bring in rules regarding transparency, equal treatment of foreign competitors, and a control mechanism of observance of

\footnotetext{
${ }^{16}$ Eight ASEAN members have at the time of writing (October 2016) accepted the Protocol of Amendment. Notable exceptions are Indonesia and Philippines (http://wto.org)
} 
rules regarding public procurement in all free-trade negotiations. This standpoint has also in the case of ASEAN countries been met with considerable resistance. The EU is at the same time also accused of limiting the opportunities for free market competition regarding procurement in the public sector in different member countries, e.g. due to the use of government subsidies to uncompetitive industries, and regional policy cohesion practises.

\section{Empirical study}

The interviews with representatives of public and private institutions were carried out to establish which concrete issues could be expected in advance; next, which ones were identified during the negotiations, how had they in such a case had been addressed, and, finally, whether these disunities had been solved or remained in the final compromise. These interviews took place between 2007 and 2014, i.e. both in the initial phases of the negotiations, and after the conclusion of the final deal. The interviews with the private companies, representing different sectors within service industries, aimed thereafter to verify solved or unsolved problems at the business level within respective industry, and took place in November-December 2014, i.e. after the concluded deal, but before the agreement's entry into force. The business actors were categorised along two dimensions, namely their degree of dependence on a domestic physical infrastructure to carry out the service, and the degree of being restrained by domestic regulations regarding this particular service (see Fig. 3). Nine out of the thirteen respondents were dependent on a local physical infrastructure to a relatively low degree, and, thus highly mobile regarding their own location. The main purpose of being located in Singapore was to offer a service to local customers and not to provide for exports to the EU. In this respect, the result of the EUSFTA negotiations were claimed to have little direct importance for them, but indirectly more relevant in terms of a gradual relief of domestic regulations, constituting various technical barriers to trade. As had already

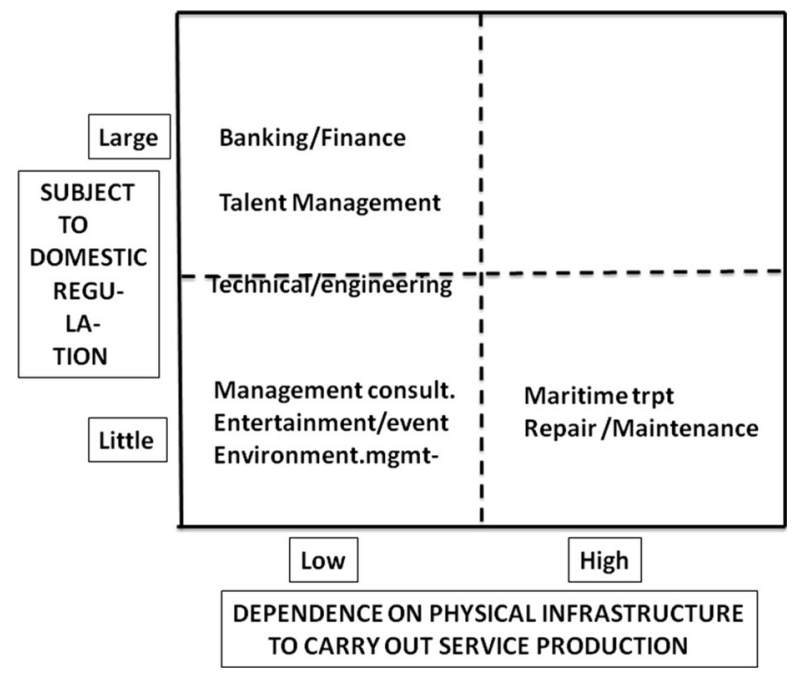

Fig. 3 Categorisation of interviewed service companies 
been established in the interviews with the official actors, Singapore keeps few important technical barriers to trade, why harmonisation and standardisation were not big issues. The major prevailing barriers, which were also not solved in the agreement, were identified within the financial sector, and regarding the lack of completely mutual acceptance of professional qualifications. These restraints were confirmed by the interviews with financial actors and in talent management, but were at the same time treated pragmatically, since these restrictions had existed already at the time of establishment, and a sufficient niche of business could be conducted within these limits anyway. The Singaporean education system is better fit for solving barriers regarding technical consultants, than in general management consultancy. Local presence and close connections to customers, both domestic and foreign originated, were considered to be crucial, regardless of existing and potentially reduced technical barriers. The majority of clients were still foreign with an overrepresentation of the home-countries of the responding service firms, but the shares of domestic and Asian clients were increasing. All business respondents looked positively forward to the agreement to be implemented, but saw relatively few direct short-term benefits of the deal. Instead, a future interregional EU-ASEAN agreement, using the EUSFTA as the minimum level of reciprocal legislation, was considered to have a much larger potential impact on their business, since the opportunity to use Singapore as a hub for offering knowledgeintensive business services to other ASEAN members remained limited by the existing barriers, and the majority of the respondents had been forced to create parallel local companies in other member states in order to avoid these barriers. A large technical/ engineering consultant firm had opened their office in Singapore in 1991 in order to serve the entire ASEAN region. Yet, they do still have projects in countries where they do not have an office; in that case they conduct the planning work in their office in an ASEAN member state outside Singapore by using local partners and following the domestic regulations in the location of the project. The customers also require this proximity: [Even] ' $\ldots$ those who have been our customers for 20-30 years, still stipulate the planning to be done at the site. They want to control it ...', according to this firm.

The location of a hub in Singapore was also convenient for personal and logistical reasons, in terms of the school system, flight connections etc. Even though IPR charges represent the sector with the largest deficit in the bilateral balance with the EU, those respondents who had experiences of these issues did not see them as problems; some did specifically compare Singapore favourably to other countries in Asia, particularly India and Mainland China.

The four respondents which were categorised as more dependent on a local physical infrastructure to conduct and to offer business services in Singapore, i.e. within the transport and maritime repair/maintenance sector, were, not surprisingly, less concerned with any significant technical barriers to trade; if they were, they should presumably not be present at all. They were also more active in offering services to customers outside Singapore within ASEAN and to other countries in East Asia. They did also emphasise the active engagement by Singapore's government to construct rules that made the local establishment of a business hub more attractive. Two global European manufacturing companies among the respondents run sales/service/administrative units in Singapore with the objective to grow in the maintenance business. Maintenance is regarded an important business area for which they must be locally present, and most of the 
customers are local companies. Therefore they run in parallel units in at least five other ASEAN countries.

In this context, it was also noted by several respondents, official actors as well as the private firms, that if the TPP comes into force, there are uncertainties regarding how to interpret the relations between those ASEAN states, including Singapore, which are TPP members, and those, which are not, in a case if and when TPP comes into force before an EUSFTA. The slowly proceeding deepening integration process within ASEAN/AFTA, specifically the AEC 2015 scheme, was also mentioned, but was not expected with too high optimism. Potential problems regarding effects of the WTO-orchestrated TiSA negotiations, in which Singapore is not a partner, but the EU is, were not particularly mentioned, and obviously at this stage being too esoteric to pay attention to at the business level. Several respondents stressed that a global WTO solution would be the best option, but the problem is its slowness. One respondent argued that ' ... the 500 FTAs are something that nobody can grasp. They do not have any kind of guiding effect that they should have'.

To sum up, all business respondents adopted a reactive rather than a proactive attitude to the EUSFTA. They were fairly well familiar with the deal and its potential, as well as with other trade policy talks in the region. Some were also participating in interest- and lobby organisations, to keep informed about ongoing discussions, but were rather adapting an 'ad-hoc' attitude to various technical barriers to trade, in order to find pragmatic solutions. The awareness among firms of the various FTAs seems to have increased during the last decade, as earlier studies indicated lower responsiveness of firms to the FTAs than the more recent ones (Kawai and Wignaraja 2011b; Kettunen 2012; Wignaraja 2015, p. 194). With the exception of a few limited areas, the business climate in Singapore was considered to be better than in most other parts of the world, why an EUSFTA taken into force could rather be seen as a normative 'spearhead' for other deals, in which respect an EU-ASEAN agreement was seen as an important step, particularly in order to strengthen Singapore's role as a regional hub for service trade.

\section{Conclusion}

The paper has taken its departure at the increased significance of service trade in the global economic development. From being considered a less-important part of world trade and FDI, services are now considered crucial for sustaining and developing economic growth in mature, as well as in emerging markets. However, much is still to be done within the field of service trade agreements, and underlying national differences complicate the possibility to reach multilateral agreements and to develop the intentions of the GATS and in the current TiSA negotiations. In this context, the proliferation of various kinds of preferential trade agreements - bilateral, regional and interregional - can be seen as a sign of acknowledging the economic importance of services in the transformation of mature and emerging markets in the absence of a completion of the Doha Development Agenda, since they at the same time also reach levels beyond what can be agreed multilaterally. The soon to be realised EU-Singapore FTA reflects the willingness to push these issues forward in relation to the overall economic importance of trade and FDI. This endeavour is also related to the economic relationship between Singapore and the rest of ASEAN, as well as with Japan, China and other countries in the region, and to the recently concluded, but not yet ratified TPP 
agreement. The UK decision to initiate an exit from the EU will indeed add to uncertainty regarding its future role in international service trade, both regionally between the UK and EU, and globally within a TiSA framework. The firm-level perspective will be of great importance in relation to location strategy in Asia in order to build competitive advantage. UK firms have traditionally been able to utilise their close relationship with Singapore as a location-specific advantage in the knowledgeintensive business service industry development in Asia. However, all major players are eager to develop a mutually beneficial relationship for future service-related growth. Singapore is an important case, since its government has worked hard to establish the city state as a service and knowledge hub, in competition with other cities in the region. Favourable location-specific factors in combination with a strong institutional environment seem to be particularly positive for attracting service FDI. The difficulty of measuring the value added within services makes further case study of the sectors increasingly relevant (Hamanaka 2011a, b). The complexity of services embedded in production networks also calls for these kinds of studies. Interviews with trade officials at both parties confirm that this agreement is seen as a pilot case for future 'WTO-plus' agreements, going beyond trade in goods, through the inclusion of investment, all kinds of services, public procurement, competition policy and trade facilitation issues. Interviews with respondents from different service sectors at the company level confirmed that most firms have so far adopted a passive and reactive attitude, playing a waiting-game, and are maintaining an 'ad-hoc' approach to rules and regulations that may change to the better after the implementation of the agreement. Despite a general confusion regarding which of several overlapping and partly contradictory PTAs to take advantage of in a separate business transaction, most companies tended to turn such an uncertainty into a competitive advantage by jumping between different existing agreements in order to benefit from the best option in each separate case. Such a strategy requires, though, a better insight and a more profound legal interpretation of the different agreements than the normal service business firm possesses, why the real benefits from such a strategy are limited. The key difference between service sub-sectors and their ability to take advantage of the realisation of the EUSingapore FTA is furthermore related to their dependence of local infrastructure, and their mobility between different geographic locations in order to provide the service. It was further confirmed that even though Singapore represents a highly liberalised trade and investment régime, there are a number of technical barriers to trade remaining, not only in direct trade with Singapore, but to an even larger extent in entrepôt transactions with other ASEAN members and other countries in the Asia-Pacific region (cf. Hill and Menon 2014, p. 19; Wignaraja 2015, p. 194). The service sector lags behind manufacturing when it comes to mutually acceptable comprehensive rules in the day-to-day practises. In particular, various business services that today are encapsulated in a physical product, but nevertheless account for a major share of the compound value added of the final product, need more attention and regulation in future comprehensive free-trade agreements, regardless of whether they represent the multilateral or the regional/interregional level.

Acknowledgements The authors are grateful to Dr. Lena Lindberg, now at the Permanent Representation of Sweden to the European Union, Brussels, for being the principal investigator during the first round of fieldwork, and to Dr. Cheryl M. Cordeiro, Centre for International Business Studies, who planned and took part in the interviews during the second round. Erja Kettunen wishes to thank the Finnish Foundation for Economic Education for financing her part of the study. 


\section{Appendix}

\section{Interview guide}

*Type of business.

-How long time in Singapore;

-Number of employees: expatriates/locals.

*Production and trade.

-Main reasons for locating in Singapore;

-Other activities within ASEAN; Singapore as a hub;

-Service imports, value added in Singapore, sales/customers in Singapore, service exports;

-Countries of origin, countries of purchase, countries of sales, countries of final consumption; (ASEAN, Other AsPac, EU, USA).

-Relation to manufacturing: imports, services embedded in manufactured products for domestic sales and/or exports.

*External trade environment.

-Knowledge about EUSFTA, other Singapore FTAs, TPP, TTIP, China-ASEAN etc.

*Technical barriers to trade.

-Problems related to imports/exports;

-Problems related to domestic rules and regulations;

-Mental barriers;

-Potential improvements after EUSFTA implementation.

*Location advantages.

-Incentives for location/expansion in Singapore;

-Business search (suppliers, customers, competitors);

-Support from public sector, universities etc.;

-Singapore in relation to ASEAN, China, AsPac;

-Prospects/threats at short/middle-term.

Open Access This article is distributed under the terms of the Creative Commons Attribution 4.0 International License (http://creativecommons.org/licenses/by/4.0/), which permits unrestricted use, distribution, and reproduction in any medium, provided you give appropriate credit to the original author(s) and the source, provide a link to the Creative Commons license, and indicate if changes were made.

\section{References}

Monographs and articles

ADB (2012) Asian development outlook 2012 update: services and Asia's future growth. Asian Development Bank, Manila

ADB (2014) Asian development outlook 2014 update: Asia in global value chains. Asian Development Bank, Manila Ahnlid A (2012) The EU meeting the Asian trade challenge - from follower to forerunner? In: Oxelheim (ed) EU/ Asia and the Re-polarisation of the global economic arena. World Scientific Press, Singapore, pp. 95-123

Ahnlid A, Alvstam CG, Lindberg L (2011) A world without Verona walls: new challenges for the external trade policy of the EU in a resilient global economy - with a special focus on Asia. In: Alvstam, 
Jännebring, Naurin (eds) I Europamissionens tjänst. Centre for European Research, Gothenburg, pp. 413429

Aldaba RM, Pasadilla, GO (2010) The ASEAN Services Sector and the Growth Rebalancing Model, ADBI Working Paper Series, No. 246

Alon I, Fetscherin M, Gugler P (eds) (2012) Chinese international investments. Palgrave Macmillan, London

Alvstam CG, Dolles H, Ström P (eds) (2014) Asian inward and outward investment: new challenges in the global economy. Palgrave Macmillan, Basingstoke

Athukorala P (2011) Production networks and trade patterns in East Asia: regionalization or globalization? Asian Economic Papers 10(1):65-95

Baldwin R (2006) Multilateralizing regionalism: spaghetti bowls as building blocks on the path to global free trade. World Econ 29(11):1451-1518

Baldwin R, Thornton P (2008) Multilateralising regionalism. Ideas for a WTO action plan on regionalism. Centre for Economic Policy Research (CEPR), London

Baldwin R (2011) Trade and industrialisation after globalisation's 2nd unbundling: how building and joining a supply chain are different and why it matters. NBER working papers no. 17716. NBER, Cambridge MA

Baldwin R, Evenett S, Low P (2009) Beyond tariff: Multilateralizing non-tariff RTA commitments. In: Baldwin RE, Low P (eds) Multilateralizing regionalism: challenges for the global trading system. Cambridge University Press, Cambridge, pp. 79-141

Baldwin R, Low P (eds) (2009) Multilateralizing regionalism: challenges for the global trading system. Cambridge University Press, Cambridge

Basu Das S, Menon J, Severino R, Shrestha OL (eds) (2013) The ASEAN economic community: a work in progress. Asian Development Bank and Institute of Southeast Asian Studies, Manila and Singapore

Bergsten CF (2007) A free trade area of the Asia-Pacific in the wake of the faltering Doha round: trade policy alternatives for APEC. In: Morrison CE, Pedrosa E (eds) An APEC trade agenda?: the political economy of a free trade area of the Asia-Pacific. Institute of Southeast Asian Studies, Singapore, pp. 15-36

Bhagwati J (2008) Termites in the trading system: how preferential agreements undermine free trade. Council on Foreign Relations, New York

Bhagwati J, Greenaway D, Panagariya A (1998) Trading preferentially: theory and policy. Econ J 108(449): $1128-1148$

Chaisse J, Gugler P (eds) (2009) Expansion of trade and FDI in Asia: strategic an policy changes. Routledge, New York

Chia SY (2011) Singapore. In: Kawai M, Wignaraja G (eds) Asia's free trade agreements: how is business responding? ADBI and Edward Elgar, pp 159-198

Coe NM, Yeung HW-C (2015) Global production networks: theorizing economic development in an interconnected world. Oxford University Press, Oxford

Coxhead I (2015) Introduction: Southeast Asia's long transition. In: Coxhead I (ed) Routledge handbook of southeast Asian economics. Routledge, New York

Dee P (2010) Deepening East Asian integration in services. In: ERIA policy Brief No 2010-01. Economic Research Institute of ASEAN and Asia, Jakarta

Dee P (2012) Mid-term review-services liberalization: impact and way forward. Association of Southeast Asian Nations, Jakarta

Drzeniek Hanouz M, Geiger T (2010) Enabling trade in the greater ASEAN region: findings from the enabling trade index 2010. World Economic Forum, Geneva

Feenstra RC (1998) Integration of trade and disintegration of production in the global economy. J Econ Perspect 12:31-50

Findlay C (2011) Services trade and investment liberalization. In: Fujita M, Kuroiwa I, Kumagai S (eds) The economics of east Asian integration: a comprehensive introduction to regional issues. Edward Elgar, Cheltenham

Fink C (2008) PTA in services: friends or foes of the multilateral trading system? In: Marchetti J, Martin R (eds) Opening markets for trade in services: countries and sectors in bilateral and WTO negotiations. Cambridge University Press, Cambridge

Fink C, Molinuevo M (2008) East Asian free trade agreements in services: key architectural elements. J Int Econ Law 11(2):263-311

François J, Hoekman B (2010) Service trade and policy. J Econ Lit 48(3):642-692

François J, Wignaraja G (2008) Economic implications of Asian economic integration. Glob Econ J 6(3):1-46

Fujita M, Kuroiwa I, Kumagai S (2011) Introduction. In: Fujita M, Kuroiwa I, Kumagai S (eds) The economics of east Asian integration: a comprehensive introduction to regional issues. Edward Elgar, Cheltenham 
Gereffi G, Humphrey J, Sturgeon T (2005) The governance of global value chains. Rev Int Polit Econ 12:78104

Hamanaka S (2011a) Examination of the Singapore Shift in Japan's Foreign Direct Investment in Services in ASEAN, ADBI Working Paper Series, No. 267

Hamanaka S (2011b) Japan's foreign direct Investment in Services in ASEAN: the implications of services and investment agreements. Journal of World Investment and Trade 12(3):351-376

Hamanaka S (2014) Asian free trade agreements and the WTO compatibility. World Scientific Publishing, London

Hill H, Menon J (2014) ASEAN commercial policy: a rare case of outward-looking regional integration. In: $A D B$ Working Paper Series on Regional Economic Integration, no. 144. Asian Development Bank, Manila

Hillman J (2010) Saving multilateralism: renovating the House of Global Economic Governance for the twenty-first century. In: Brussels forum paper series. The German Marshall Fund of the United States, Washington, DC

Hiratsuka D (2011) Production networks in the Asia-Pacific Region: facts and policy implications. In: IDEJETRO Discussion Paper, No 315. Institute of Developing Economies, Tokyo

Hoekman B, Mattoo A (2011) Services Trade liberalization and regulatory reform: re-invigorating international cooperation. In: World Bank Policy Research Working Papers 5517. World Bank, Washington, DC

Hufbauer GC, Schott JJ (2009) Fitting Asia-Pacific agreements into the WTO system. In: Baldwin, Low (eds) Multilateralizing regionalism: challenges for the global trading system. CUP, Cambridge, pp. 495-553

Ishido $\mathrm{H}$ (2011) Liberalization of trade in services under ASEAN $+n$ : a mapping exercise. In: ERIA Discussion paper Series No 2011-2. Economic Research Institute of ASEAN and Asia, Jakarta

Ishido H, Fukunaga Y (2012) Liberalization of trade in services: toward a harmonized ASEAN++ FTA' In: ERIA policy Brief No 2012-02. Economic Research Institute of ASEAN and Asia, Jakarta

Jensen JB (2013) Overlooked opportunity: tradable business services, developing Asia and growth, ADB Economics Working Paper Series, No. 326

Johnson RC, Noguera G (2012) Accounting for intermediates: production sharing and trade in value-added. J Int Econ 86(2):224-236

Kaplinsky R (2010) The role of standards in global value chains. Washington D.C, World Bank

Kawai M, Wignaraja G (2011a) Asian FTAs: trends, prospects and challenges. Journal of Asian Economics 22(1): $1-22$

Kawai M, Wignaraja G (eds) (2011b) Asia's free trade agreements: how is business responding? Asian Development Bank Institute and Cheltenham: Edward Elgar

Kawai M, Wignaraja G (2013) 'Patterns of free trade areas in Asia. In: Policy studies, No 65. East-West Center, Honolulu

Kettunen E (2012) Challenges and opportunities of firms in integrating ASEAN. In: Proceedings of the International Symposium on Economic Crisis in Europe: Perspectives from Japan, Kansai University Japan-EU Research Center Report, 2(2), pp 25-47

Koopman R, Powers W, Wang Z, Wei S-J (2011) Give credit to where credit is due: tracing value added in global production chains. In: NBER Working Papers Series, No 16426. National Bureau of Economic Research, Washington, DC

Kuroiwa I, Kumagai S (2011) 'A history of de facto economic integration in East Asia'. In: Fujita M, Kuroiwa I, Kumagai S (eds) The economics of east Asian integration: a comprehensive introduction to regional issues. Edward Elgar, Cheltenham

Lindberg L (2007) A status report on the ASEAN \& EU-ASEAN economic integration in 2007-including a pilot study on the interests of the Swedish business sector in Singapore . ISEAS/Embassy of Sweden, SingaporeApril, 2007

Lindberg L, Alvstam, CG (2009) EU-ASEAN trade facing free trade negotiations. In: Lindahl R, Cramér P (eds) Forskning om Europafrågor. Centrum för Europaforskning vid Göteborgs Universitet, skrift No 21, pp 1-19

Lindberg L, Alvstam CG (2012a) The ambiguous role of the WTO in times of stalled multilateral negotiations and proliferating FTAs in East Asia. Int Negot 17(1):163-187

Lindberg L, Alvstam CG (2012b) Interregional trade facing Repolarisation: the EU trade negotiations with ASEAN countries. In: Oxelheim L (ed) EU-Asia in the age of Repolarisation of the global economy. World Scientific Press and the Imperial College Press, London, pp. 55-94

Luo Y, Rui H (2009) An ambidexterity perspective toward multinational enterprises from emerging economies. Academy of Management Perspective 23:49-70

Luo Y, Tung RL (2007) International expansion of emerging market enterprises: a springboard perspective. J Int Bus Stud 38(4):481-498

Marchetti JA, Mavroidis PC (2011) The genesis of the GATS'. European Journal of International Law 22(3): 689-721 
Masuyama S, Vandenbrink D (2003) Towards a knowledge-based economy, East Asia's changing industrial geography. ISEAS, Singapore

Narula R (2012) Do we need different frameworks to explain infant MNEs from developing countries? Glob Strateg J 2(3):188-204

National Board of Trade (2011) Made in Sweden? A new perspective on the relationship between Sweden's exports and imports. No 2010:6. Kommerskollegium, Stockholm

Noland M, Park D, Estrade GB (2012) Developing the service sector as engine of growth for Asia: and overview, ADB Working Paper Series, No. 320

Pananond P (2013) Moving along the value chain: emerging Thai multinationals in globally integrated industries. Asian Business \& Management 12(1):85-114

Ramamurti R (2012) What is really different about emerging market MNEs? Glob Strateg J 2(1):41-47

Rizwanul Islam MD, Alam S (2009) Preferential trade agreements and the scope of GATT article XXIV, GATS article V and the enabling clause: an appraisal of GATT/WTO jurisprudence. Netherlands International Law Review 56:1-34

Roy M (2012) 'Services commitments in preferential trade agreements: Surveying the empirical landscape. In: NCCR Trade Working Paper No 2012/02

Rugman A (2009) Theoretical aspects of MNEs from emerging markets. In: Ramamurti R, Singh JV (eds) Emerging multinationals in emerging markets, pp 42-63

Sally R (2013) ASEAN FTAs: state of play and outlook for ASEAN's regional and global integration. In: Basu Das S, Menon J, Severino R, Shrestha OL, (eds) The ASEAN economic community: a work in progress. Asian Development Bank and Institute of Southeast Asian Studies, pp 320-381

Severino R, Menon J (2013) The ASEAN community: an overview. In: Basu Das S, Menon J, Severino R, Shrestha OL (eds) The ASEAN economic community: a work in progress. Asian Development Bank and Institute of Southeast Asian Studies, Manila and Singapore, pp. 1-30

Shepherd B, Pasadilla G (2012) Services as a new engine of growth for ASEAN, The People's Republic of China, and India, ADBI Working Paper Series, No. 349

Sturgeon T, Memedovic O (2011) Mapping global value chains: intermediate goods trade and structural change in the world economy. United Nations Industrial Development Organization, Vienna

Ström P (2006) Internationalisation of Japanese professional business service firms: dynamics of competitiveness through urban localization in Southeast Asia. In: Harrington JW, Daniels PW (eds) Knowledgebased services: internationalisation and regional development. Ashgate, Aldershot

Ström P, Yoshino N (2009) Japanese financial service firms in east and Southeast Asia: location pattern and strategic response in changing economic conditions. Asian Business and Management 8(1):33-58

UNCTAD (2013) World investment report: global value chains: investment and trade for development. United Nations Conference on Trade and Development, Geneva

Wignaraja G (2015) Regional trade agreements and enterprises in Southeast Asia. In: Coxhead I (ed) Routledge handbook of southeast Asian economics. Routledge, New York

Wignaraja G, Lazaro D (2010) North-South vs. South-South Asian FTAs: trends, compatibilities, and ways forward. In: United Nations University-Comparative Regional Integration Studies. UNI-CRIS Working Papers, Brugge. W-2010/3, pp 1-38

Williamson PJ, Ramamurti R, Fleury A, Leme Fleury MT (eds) (2013) The competitive advantage of emerging market multinationals. Cambridge University Press, Cambridge

Wong SK (2006) The adjustment of external tariffs in the Kemp-wan-Grinols compensation scheme. Can J Econ 39(2):544-563

WTO (2011) World trade report 2011- the WTO and preferential trade agreements: from co-existence to coherence. World Trade Organization, Geneva

Yeh A, Yang FF (2013) Producer services in China Economic and Urban Development. Routledge, London

Yueh L (ed) (2010) The future of Asian trade and growth: economic development with the emergence of China. Routledge, New York

\section{Documents and databases; other reports}

ASEAN (2016) ASEANStats Database. http://aseanstats.asean.org

ASEAN Investment Report (2015) Infrastructure investment and connectivity. The ASEAN Secretariat and United Nations Conference on Trade and Development, Jakarta

Brajanovic MM (2011) Bilateral trade development during economic downturn: the EU trade negotiations with Singapore. Master thesis in Business Administration. School of Business, Economics and Law, Gothenburg 
European Commission, Directorate-General for Trade (2015a) EU-Singapore Free Trade Agreement. Authentic text as of May 2015. Brussels, 29 June 2015

European Commission, Directorate-General for Trade (2015b) Trade for All: Towards a responsible trade and investment policy. Communication, October 14, 2015. www.trade.ec.europa.eu/doclib/2015 /october/tradoc 153846.pdf

European Commission, Directorate-General for Trade (2016a) The European Trade policy 2016. http://trade. ec.europa.eu/doclib/docs/2011/august/tradoc_148181.pdf

European Commission, Directorate-General for Trade (2016b) Trade in Goods with Singapore http://trade.ec. europa.eu/doclib/docs/2006/september/tradoc 113443.pdf

European Commission, Directorate-General for Trade (2016c) Trade in Services Agreement. http://ec.europa. eu/trade/policy/in-focus/tisa/. Last visit 10 October 2016

Eurostat (2016) Database. Luxemburg: European Statistical Office. http://epp.eurostat.ec.europa.eu. Accessed frequently January-October 2016

IMF (2016a) Direction of trade statistics quarterly, December. Washington D.C, International Monetary Fund

IMF (2016b) Direction of Trade Statistics Database. International Monetary Fund, Washington DC. Accessed frequently January-October 2016

Kuroda H (2006) 'Trade Policy Trends: Serving Business Interests'. Speech at the Asia-Europe Business Forum, Helsinki, Finland, September 10

MSITS (2010) Manual on Statistics of International Trade in Services, background document to the forty-first session, 23-26 February 2010. Statistical Commission of the United Nations, Geneva, Luxembourg, New York, Paris, Washington, D.C.

OECD/WTO (2016) Database. Statistics on trade in value added. doi: 10.1787/data-00648-en. Accessed 7 Oct 2016

Singapore Statistical Office (2016a) Singapore's International Trade in Services 2014. www.singstat.gov.sg. Accessed 25 Feb 2016

Singapore Statistical Office (2016b) Singapore's International Trade in Service Tablebuilder. www.singstat. gov.sg. Accessed 9 Feb 2016

World Bank (2012) Service with a Smile, Economic Premise, No. 96. Available at www.worldbank. org/economicpremise

WTO (2015a) WTO members conclude landmark USD 1.3 trillion IT trade deal. Press release, December 16, 2015. World Trade Organization, Geneva. www.wto.org. Accessed 4 March 2016

WTO (2015b) Trade Facilitation Agreement. World Trade Organization, Geneva. www.wto.org. Accessed 4 March 2016

\section{Personal interviews}

\section{Officials}

* Mr. Ong Keng Yong, then Secretary-General of ASEAN, the ASEAN Secretariat, Jakarta, February 21, 2007; Director of the Institute of Policy Studies, Lee Kuan Yew School of Public Policy at the National University of Singapore (NUS), Singapore, January 14, 2009.

* Ministry of Foreign Affairs, Bandar Seri Begawan, Brunei Darussalam, 8 April 2008.

* DG Trade, European Commission, Brussels, 18 November 2008.

* Ministry of Foreign Affairs, Bangkok, 22 March 2010.

* EU delegation in Bangkok, 22 March 2010.

* EU delegation in Jakarta, 24 March 2010.

* ASEAN Secretariat, Jakarta, 24 March 2010.

* Mr. Rodolfo Severino, former Secretary-General of ASEAN, Head of the ASEAN Studies Centre at the Institute of Southeast Asian Studies (ISEAS), Singapore, 25 March 2010.

* Embassy of Sweden in Singapore, 25 March 2010.

* EU delegation in Singapore, 26 March 2010.

* Mr. Ganeshan Wignaraja, Principal Economist, Office of Regional Economic Integration, ADB, Manila, 2930 March 2010.

* EU delegation in Manila, 30 March 2010.

* Ministry of Commerce, Bangkok, 31 March 2010.

* Business Sweden, Singapore, 3 November 2014.

* EU Delegation in Singapore, 3 November 2014.

* EuroCham, Singapore, 4 November 2014. 
* EU-ASEAN Business council, Singapore, 4 November 2014.

* EU Centre at the National University of Singapore, 5 November 2014.

Private companies (June 2009 and November-December 2014)

-Talent management; recruitment

-Financial market actors (2)

-Banking

-Maritime transport, reparation/maintenance (4)

-Technical/engineering consultants (3)

-Management consultant

-Entertainment; event management

-Environmental management 